\title{
ANALYSIS OF THE ECONOMIC VIABILITY OF A RURAL TOURISM ENTERPRISE IN BRAZIL: AN APPLICATION OF THE MONTE CARLO METHOD
}

Fernando Rodrigues Amorim Universidade Estadual de Campinas, Brazil E-mail: fernando.amorim@feagri.unicamp.br

Bianca Regina Ferreira Silveira Fundação Educacional de Barretos, Brazil E-mail: biahsilveira3@gmail.com

Edilene Alves dos Santos Fundação Educacional de Barretos, Brazil E-mail: edilenealvesds@gmail.com

Pedro Henrique Camargo de Abreu Centro Paula Souza, Brazil E-mail: phcamargo1997@gmail.com

Juliana Rosa Tostes Universidade de São Paulo, Brazil E-mail: jrosatostes@yahoo.com.br

Submission: $17 / 04 / 2017$ Revision: 11/05/2017 Accept: 16/05/2017

\section{ABSTRACT}

The acquisition of projects aimed at rural tourism represents an alternative for generating income. The objective of this study was to evaluate the viability of purchasing a farm that is structured as a hostel, located in Joanópolis, interior of São Paulo, Brazil. The method was based on exploratory research based on a case study comparing the economic viability of this project. However, this viability is surrounded by uncertainties and risks. With this, the Monte Carlo method was used to analyze this probability. The data were obtained through the Department of Tourism in the city of Joanópolis from primary and secondary data. The calculations were made for work during a year drawn up in a cash flow with the monthly 
INDEPENDENT JOURNAL OF MANAGEMENT \& PRODUCTION (IJM\&P)

http://www.ijmp.jor.br

v. 8, n. 4, October - December 2017

ISSN: 2236-269X

DOI: 10.14807/ijmp.v8i4.662

expenses of the hostel. From the results it was concluded that it is feasible to buy this hostel in the real and optimistic scenario and in the Monte Carlo method analyzing the project's total NPV values.

Keywords: Monte Carlo method; simulation; economic viability; scenario analysis.

\section{INTRODUCTION}

Tourism, in addition to being very favorable for the entrepreneur who ventures on the scene, also generates expressive results for the community, encourages the economy and cultural production.

According to Sanovicz (2011), the tourist is guided by basic reasons that are summarized in four verbs: eating, sleeping, shopping and visiting. What drives them to make the decision in choosing a particular location is the reason why it separates holidays and leisure, business and events, visiting relatives, tasting a food or a drink, plus dozens of other reasons we can imagine.

However, tourism generates a set of experiences and perspectives. This sector fits into the service sector and provides particular, momentary and intangible experiences.

Kotler and Keller (2012) define service as any essentially intangible act or performance that one party can offer to another and that does not result in ownership of anything; this service may or may not be linked to a concrete good, there is still the characteristic that there is no way to produce the service without its consumption being concomitant.

In other words, Cooper et al. (2011) believe that even though it is inserted in the services sector, tourism does not only provide the intangible, since it has tangible areas such as gastronomy, comfort offered by hotel facilities, all products that the tourist can acquire; in addition to all the infrastructure offered by the places of visitation.

Still according to the same authors, despite all the tangible assets, resources and infrastructure that are necessary for tourism to take place, what has the greatest value for the tourist is experience; an interrelationship between producer and consumer is created, where this experience is generated. 
INDEPENDENT JOURNAL OF MANAGEMENT \& PRODUCTION (IJM\&P)

http://www.ijmp.jor.br

v. 8, n. 4, October - December 2017

ISSN: 2236-269X

DOI: 10.14807/ijmp.v8i4.662

Maximiano (2011) demonstrates that a system is a set of parts that interact and function as a whole. However, Cooper et al. (2011) consider the most elementary form of tourism, which can be understood as the set of consumption, production and experiences generated.

Silva et al. (2010) report that the vital studies for the success of an enterprise focused on rural tourism are: quality in services, hygiene and cleanliness, gastronomy and cultural identity; also consider Brazil favored for the practice due to the variety of cultures brought by the colonization process and, added to the diversity, there is the characteristic hospitality of the Brazilian, especially the one of the inhabitant of the interior.

These authors also explain that rural tourism provides a new alternative for the development of rural communities, and complements the family income of the agricultural units that appropriate the tourism proposal through offers of activities related to leisure, sports, culture, gastronomy, hosting and productive techniques.

The destination that the tourist chooses is central element that contributes to the consumption and the production of the tourism, and today stands out the increasing offer of said rural tourism, justified by the increasing demand of the society in search of places that offer tranquility and simplicity of the interior, and also by the great incentive of governmental and non-governmental bodies to such ventures; therefore, the objective of this article is to verify the economic viability of an investment in a rural hostel, which aims at the utilization of natural, historical, cultural and gastronomic resources.

\section{MATERIALS AND METHODS}

According to the objective of this work, it is characterized as exploratory research. Gil (2002) reports that this type of research provides a greater familiarity with the problem in a way that allows ample and detailed knowledge about a certain subject.

With regard to development, this research is considered as a case study, carried out from the analysis of the investment in the purchase of a hostel, inserted in the Atlantic Forest and divided into apartments that can be individual, for a couple, a couple with children and groups of up to 6 people. 
INDEPENDENT JOURNAL OF MANAGEMENT \& PRODUCTION (IJM\&P)

http://www.ijmp.jor.br

v. 8, n. 4, October - December 2017

ISSN: 2236-269X

DOI: 10.14807/ijmp.v8i4.662

It has all the infrastructure ready to receive the tourist, as well as options such as convenience store, event room and whirlpool, which allow diversification and increase the attractiveness of the business.

The Tourist Resort of Joanópolis is only $120 \mathrm{Km}$ from the Capital São Paulo and is easily accessible by the Highways Fernão Dias and Dom Pedro I, being famous for the mild climate with temperatures that do not exceed $19^{\circ}$, it is also part of the circuit between mountains and waters, an association that encourages the tourist development of its member cities.

According to information provided by the Tourism Secretariat, the municipality, which is the site of the hostel, has about 12,800 inhabitants. It also receives large numbers of tourists in the times of the typical Feast of St. John and in the summer months, and smaller quantities in winter, where temperatures are lower.

\subsection{Case study}

The purpose of the case study is not to provide the precise knowledge of the characteristics of a population, but to allow a global view of the problem, or to identify possible factors that influence or are influenced by it. Another contradiction concerns time, when it says that it takes a long time for its realization and its results become less consistent (GIL, 2002).

According to Yin (2001) and Stake (2000), the definitions of a set of steps that can be used in the so-called case study are: problem formulation; unit-case definition; determination of the number of cases; elaboration of the protocol; data collect; evaluation and analysis of the data and preparation of the report.

Raising the formulation of the problem is the initial stage of the research, in the case study it is not appropriate to develop explanations of characteristics of a population to measure the level of correlation between variables, or to verify causal hypotheses. It is most commonly used for exploratory and descriptive studies.

For example, when you want to check how much a population consumes, a survey is carried out, and if you want to verify the reasons that determine the preference for a particular product, the survey may be insufficient and, therefore, it is suggested to perform a case study (GIL, 2002). Therefore, based on these procedures mentioned above, the research is characterized as a case study. 
DOI: 10.14807/ijmp.v8i4.662

\subsection{Economic viability}

Today, due to the greatness and complexity of the world economy, and the need for companies to adapt for the dynamism, the tools that help in the management are extremely important and of great general use.

When it comes to investing in a new business project or even a new venture, several authors consider it of great importance that the economic viability of the project is verified, so that only investment safety can be achieved. Sviech and Mantovan (2013) explain that for this there are a set of techniques that seek to establish these viability indicators and are often used for this purpose, among them IRR, NPV and Payback.

The aforementioned authors also explain that it is not interesting to make decisions based on only one of the tools, since each one has shortcomings in investment projects that have different useful lives and characteristics.

Therefore, for this work three tools were used to analyze how feasible is the investment in the purchase of the said rural inn: Internal Rate of Return (IRR), Net Present Value (NPV), Payback Period.

According to Batalha (2009), the most used methods to analyze the selection of investment opportunities are: NPV, IRR and Payback Period. In order to analyze the economic viability, it was necessary to draw up a cash flow that demonstrates the entry and exit of all the products and resources necessary for the operation of the inn.

Jerônimo (2013) also considers that the indicators are strongly influenced by the operational variables, which help in the oscillations of costs, revenues and market dynamics. Based on this, it was decided to consider scenarios with high and low seasons, as well as the construction of the scenarios of risks characterized by the optimistic $(+10 \%$ of expected result), real and pessimistic $(-10 \%$ of expected result) that will generate a more assertive analysis of investment.

According to Motta and Calôba (2002), the NPV is expressed by the algebraic sum of discounted cash flows for the present instant, at an interest rate. According to Bruni et al. (1998), NPV is characterized as the difference between future cash flows transferred to a present value by the opportunity cost of capital and the initial investment. 
INDEPENDENT JOURNAL OF MANAGEMENT \& PRODUCTION (IJM\&P)

http://www.ijmp.jor.br

v. 8, n. 4, October - December 2017

ISSN: 2236-269X

DOI: 10.14807/ijmp.v8i4.662

A positive NPV means that the project will cover the initial investment, already discounting an expected rate of return and will also generate additional resources, providing benefits to investors. In the case of negative NPV, it means that the project will not generate enough resources to meet the invested capital, considering the required rate of return, and it is clear that its implementation is not viable.

Payback is the period it needs to be able to recover its invested capital. In other words, Gitman (2002) reports that it is possible to verify how long it will take for the investor to have a return on investment. Payback is used to calculate how much time it will take to cover spending on the investment. However, Lapponi (2000) corroborates that payback identifies and specifies the time required for investment recovery, complementing NPV and IRR.

The use of the IRR method does not have a specific capital cost as well as the NPV; but, otherwise, its purpose is to discover an intrinsic rate of income (SAMANEZ, 2001)

The IRR is the maximum rate of return that an investment can verify to be viable; a widely used tool to evaluate the expected return on each investment. To be sure your investment will have a good return, your IRR has to be greater than zero.

From the cash flows were determined the NPV, considering a rate of $10 \%$; the IRR, which makes the present value of the net flow equal to zero at the initial moment; and finally the Payback Period was made, which establishes the time necessary for recovery of capital.

The projection of future cash flows considers the variables that influence the operation of the company and the projection of the expected results. The identification of the value drivers of the business was based on the analysis of the historical statements and on macroeconomic variables that consider the economic, social and political environment in which the company is inserted.

Regarding the interpretation and analysis of data, the research has a quantitative character, as it will demonstrate data on values and costs. However, this type of research serves to analyze the information and show how everyone can understand the numbers and/or data, the information acquired so they can classify and analyze. 
INDEPENDENT JOURNAL OF MANAGEMENT \& PRODUCTION (IJM\&P)

http://www.ijmp.jor.br

v. 8, n. 4, October - December 2017

ISSN: 2236-269X

DOI: 10.14807/ijmp.v8i4.662

However, the qualitative research aims to quantify the data and criteria of large representative samples, using statistical analysis (MALHOTRA et al., 2010).

Investment analysis is based on the use of techniques to identify the best investment allocation among the various alternatives. When processing the data, equations and calculations related to the asset, it is possible to see if there is a profitability, how much it can be and whether the investment is working or not. Therefore, it can be said that this analysis is indispensable when considering the realization of an investment, since it proves to be a very good tool to support the decision of the investor. Since every investment has a risk involved, the investment analysis will help minimize them.

According to Correia Neto et al. (2002), the Monte Carlo simulation is the most complete method of measuring the risk of the company's cash flows, since it is more dynamic in the analyzes of the volatilities of the flows and captures in a more efficient way the relationship between the variables that compose the flow of the company.

\subsection{Monte Carlo method}

The next step was to use the Crystal Ball software option to run the Monte Carlo method simulation application. Rodrigues et al. (2010), state that this type of analysis is randomly generated results and recorded in the worksheet numerous times, guaranteeing a statistical confidence level of 95\%, which means that the results generated by the simulation will be $95 \%$ of the time within the average range population. The confidence level adopted in the present study is the same as in the study cited.

For the application of the Monte Carlo simulation, it was necessary to use the results obtained from the criteria mentioned above, so that the simulation was able to take into account the totality of the company due to the project. Only in this way would it be possible to identify and reach a conclusion on the feasibility of the investment.

Moore and Weatherford (2005) argue that in many cases, simulation models are applied to analyze a decision that involves risk. This risk is present in a model in which the behavior of one or more factors cannot be defined with certainty. In this 
INDEPENDENT JOURNAL OF MANAGEMENT \& PRODUCTION (IJM\&P)

http://www.ijmp.jor.br

v. 8, n. 4, October - December 2017

ISSN: 2236-269X

DOI: 10.14807/ijmp.v8i4.662

case, these factors are known as random variables, and their behavior is represented by a probability distribution.

According to Lustosa et al. (2004, p. 251), the Monte Carlo simulation consists of a method that "uses the generation of random numbers to assign values to the system variables to be investigated."

In order for the Monte Carlo simulation to be correctly applied, Lustosa et al. (2004) indicate that the simulation should be replicated more than one hundred times to provide a representative sample. However, there is no rule regarding the maximum number of simulations to be performed. On the other hand, as basic instruction, the greatest number of simulations should be applied due to the processing power of the equipment used.

According to Doucet (2004), the objective of the Monte Carlo simulation is to present the probability distribution of the dependent variable analyzed, through the behavior of the independent variables that somehow affect it. The result generated is not a single value, but a sample of values obtained through a random set of data created, from their respective probability of occurrence and measures.

In Monte Carlo simulation, at each iteration, the result is stored and, at the end of all the repetitions, a frequency distribution is generated through the sequence of results obtained, allowing the calculation of descriptive statistics, such as: average (expected value), minimum value, maximum value and standard deviation. Thus, the executor of the simulations, would be responsible for idealizing future scenarios of operation of the system under analysis (SARAIVA JÚNIOR et al., 2011).

The Monte Carlo method can be used in the investment analysis, by means of the continuous and random generation of numbers that are connected in the inputs and outputs of cash used in the calculation of the NPV. Such changes in cash flow work as random scenarios. Randomly generated numbers obey predefined probability distributions, based on data obtained from the analysis of past events or using projections for the future. The definition of probability distributions is made on factors that compose the NPV calculation, such as sales growth and profit per year, where the act of randomly generating these factors causes NPV to assume several values (OLIVEIRA, 2008).

In order to operationalize the SMC, the following steps must be followed: 
INDEPENDENT JOURNAL OF MANAGEMENT \& PRODUCTION (IJM\&P)

http://www.ijmp.jor.br

v. 8, n. 4, October - December 2017

ISSN: 2236-269X

DOI: 10.14807/ijmp.v8i4.662

- Define the variables involved in the system under analysis based on past data or subjective estimates of managers;

- Construct the frequency distributions (absolute, relative and accumulated) for each one of the defined variables;

- Define for each variable considered, the class or incidence intervals of the random numbers, based on projected cumulative frequency distributions;

- Generate random numbers;

- Incident random numbers generated in intervals of each class of each level;

- Simulate the experiments.

\section{RESULTS AND DISCUSSION}

The initial investment forecast was $\mathrm{R} \$ 3.232 .596 .92$. This value is based on projects with inn characteristics. However, $\mathrm{R} \$ 4.003,36$ of fixed costs was related.

The variable costs were $\mathrm{R} \$ 242.917,50$, allocated to customer demand variations over the course of a year.

Cash flow was projected to 10 (ten) years, and growth rates were included over the course of these ten years, based on the growth prospects of tourism in the region, with 10\% growth in the first 5 years and 5\% in the next 5 years.

We also considered the real, pessimistic and optimistic risk scenarios that returned investment expectations between the 5th and 6th year of operation.

Table 1 below shows the result of the actual scenario.

Table 1: Real Scenario

\begin{tabular}{|c|c|c|}
\hline Years & NPV & Balance \\
\hline 0 & $-R \$ 3.232 .596,92$ & $-\mathrm{R} \$ 3.232 .596,92$ \\
\hline 1 & $\mathrm{R} \$ 456.542,18$ & $-\mathrm{R} \$ 2.776 .054,74$ \\
\hline 2 & $\mathrm{R} \$ 502.196,40$ & $-\mathrm{R} \$ 2.273 .858,34$ \\
\hline 3 & $\mathrm{R} \$ 552.416,04$ & $-\mathrm{R} \$ 1.721 .442,30$ \\
\hline 4 & $\mathrm{R} \$ 607.657,64$ & $-\mathrm{R} \$ 1.113 .784,66$ \\
\hline 5 & $\mathrm{R} \$ 668.423,41$ & $-\mathrm{R} \$ 445.361,26$ \\
\hline 6 & $\mathrm{R} \$ 701.844,58$ & $\mathrm{R} \$ 256.483,32$ \\
\hline 7 & $\mathrm{R} \$ 736.936,80$ & $\mathrm{R} \$ 993.420,12$ \\
\hline 8 & $\mathrm{R} \$ 773.783,65$ & $\mathrm{R} \$ 1.767 .203,77$ \\
\hline 9 & $\mathrm{R} \$ 812.472,83$ & $\mathrm{R} \$ 2.579 .676,60$ \\
\hline 10 & $\mathrm{R} \$ 853.096,47$ & $\mathrm{R} \$ 3.432 .773,07$ \\
\hline \multicolumn{2}{|c|}{ Estimated Return Rate } & $12,25 \%$ \\
\hline PAYBACK & 5,634558237 & 5 years 7 months and 18 days \\
\hline NPV & \multicolumn{2}{|c|}{$\mathrm{R} \$ 262.908,86$} \\
\hline IRR & \multicolumn{2}{|c|}{$14 \%$} \\
\hline
\end{tabular}


INDEPENDENT JOURNAL OF MANAGEMENT \& PRODUCTION (IJM\&P)

http://www.ijmp.jor.br

v. 8, n. 4, October - December 2017

ISSN: 2236-269X

DOI: 10.14807/ijmp.v8i4.662

The results showed that all the analyzes were positive and satisfactory, being feasible the investment in this scenario.

It is possible to compare the values obtained in this scenario with the study of Ires (2013), which consists of a similar analysis in relation to rural tourism, where the author obtained a NPV of $€$ 913,749, an IRR of $57.41 \%$ and a Payback Period of 4 years. Therefore, the values obtained in the real scenario have a lower IRR and Payback Period in the comparison. However, the project can be considered profitable.

When comparing with the work of Cabral (2016), the author obtained a NPV of $€ 304,474$ in the Expected Scenario, considered viable by him. In addition, the author obtained a IRR of $12.43 \%$, and a Payback Period of approximately 6 years and 7 months.

Table 2 below shows the results of the optimistic scenario, 10\% more than the real one.

Table 2: Optimistic Scenario (10\% more than the real)

\begin{tabular}{|c|c|c|}
\hline Years & NPV & Balance \\
\hline 0 & $-R \$ 3.232 .596,92$ & $-R \$ 3.232 .596,92$ \\
\hline 1 & $\mathrm{R} \$ 502.196,40$ & $-R \$ 2.730 .400,52$ \\
\hline 2 & $\mathrm{R} \$ 552.416,04$ & $-\mathrm{R} \$ 2.177 .984,48$ \\
\hline 3 & $\mathrm{R} \$ 607.657,64$ & $-\mathrm{R} \$ 1.570 .326,84$ \\
\hline 4 & $\mathrm{R} \$ 668.423,41$ & $-R \$ 901.903,43$ \\
\hline 5 & $R \$ 735.265,75$ & $-R \$ 166.637,68$ \\
\hline 6 & $\mathrm{R} \$ 808.792,32$ & $\mathrm{R} \$ 642.154,65$ \\
\hline 7 & $\mathrm{R} \$ 889.671,56$ & $\mathrm{R} \$ 1.531 .826,20$ \\
\hline 8 & $\mathrm{R} \$ 978.638,71$ & $\mathrm{R} \$ 2.510 .464,91$ \\
\hline 9 & $\mathrm{R} \$ 1.076 .502,58$ & $\mathrm{R} \$ 3.586 .967,50$ \\
\hline 10 & $\mathrm{R} \$ 1.184 .152,84$ & $\mathrm{R} \$ 4.771 .120,34$ \\
\hline \multicolumn{2}{|c|}{ Estimated Return Rate } & $12,25 \%$ \\
\hline PAYB & 5,206032715 & 5 years 2 months and 14 days \\
\hline NPV & \multicolumn{2}{|c|}{$R \$ 858.596,21$} \\
\hline IRR & \multicolumn{2}{|c|}{$18 \%$} \\
\hline
\end{tabular}

The results showed that NPV in this scenario was higher by $R \$ 595,687.35$ than the real scenario, the IRR was higher by $4 \%$, and the Payback Period was lower by 154 days.

Table 3 below shows the results of the pessimistic scenario, 10\% less than the real one.

Table 3: Pessimistic Scenario (10\% less than the real) 
INDEPENDENT JOURNAL OF MANAGEMENT \& PRODUCTION (IJM\&P)

http://www.ijmp.jor.br

v. 8, n. 4, October - December 2017

ISSN: 2236-269X

DOI: 10.14807/ijmp.v8i4.662

\begin{tabular}{|c|c|c|}
\hline Years & NPV & Balance \\
\hline 0 & $-\mathrm{R} \$ 3.232 .596,92$ & $-\mathrm{R} \$ 3.232 .596,92$ \\
\hline 1 & $\mathrm{R} \$ 410.887,96$ & $-\mathrm{R} \$ 2.821 .708,96$ \\
\hline 2 & $\mathrm{R} \$ 451.976,76$ & $-R \$ 2.369 .732,20$ \\
\hline 3 & $\mathrm{R} \$ 497.174,43$ & $-\mathrm{R} \$ 1.872 .557,77$ \\
\hline 4 & $\mathrm{R} \$ 546.891,88$ & $-\mathrm{R} \$ 1.325 .665,89$ \\
\hline 5 & $\mathrm{R} \$ 601.581,07$ & $-R \$ 724.084,82$ \\
\hline 6 & $\mathrm{R} \$ 631.660,12$ & $-R \$ 92.424,70$ \\
\hline 7 & $R \$ 663.243,12$ & $\mathrm{R} \$ 570.818,42$ \\
\hline 8 & $R \$ 696.405,28$ & $\mathrm{R} \$ 1.267 .223,70$ \\
\hline 9 & $\mathrm{R} \$ 731.225,54$ & $\mathrm{R} \$ 1.998 .449,24$ \\
\hline 10 & $\mathrm{R} \$ 767.786,82$ & $\mathrm{R} \$ 2.766 .236,06$ \\
\hline \multicolumn{2}{|c|}{ Estimated Return Rate } & $12,25 \%$ \\
\hline PAYBACK & 6,139352671 & 6 years 1 month and 20 days \\
\hline NPV & \multicolumn{2}{|c|}{$-\mathrm{R} \$ 86.641,72$} \\
\hline IRR & \multicolumn{2}{|c|}{$12 \%$} \\
\hline
\end{tabular}

The results showed that, in this scenario, NPV was negative, IRR was $2 \%$ lower than the real scenario, and the Payback Period was 341 days higher than the real scenario.

According to the Payback Period analysis, it is possible to conclude that the investment will bring returns in all scenarios. In the pessimistic scenario, the return will be provided in a period 6 months higher when compared to the real scenario. However, the fact that the estimated NPV is negative, indicates that the project cannot be treated as feasible.

To perform the simulation, you must be informed of the number of evaluations that will be performed. Thus, the number of evaluations for the present study was 50,000 evaluations, a considerably high number and capable of providing considerable estimates.

Through the execution of the simulation it was possible to obtain some information, such as: frequency, minimum, average and maximum project NPV, median, among other information.

Through the simulation, it was possible to observe that the average obtained for the project's total NPV was $R \$ 3,656,620.33$. This value is higher than the NPV of the real scenario, estimated at $\mathrm{R} \$ 853,096.47$. The minimum value found in the simulation for the project's total NPV was $R \$ 3,102,679.69$, which is $R \$$ $2,334,892.87$, higher than the sum of the pessimistic NPV. The maximum NPV found in the simulation was $R \$ 4,358,873.26$, which is $R \$ 748,279.58$ lower than the sum of the optimistic NPV. 


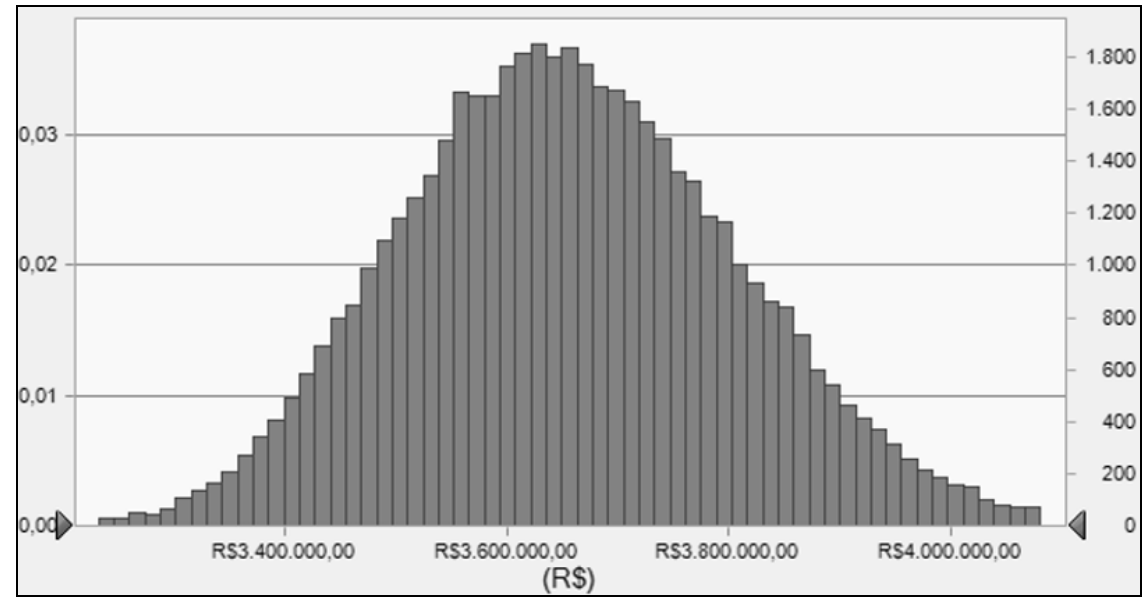

Figure 1: Frequency Graph of Project's Total NPV forecast

According to Garcia et al. (2010), the range or amplitude refers to the difference between the maximum and minimum points. However, in the comparison of this work, we can see the great distance between the extreme points of the real values and the simulated ones, as well as the great difference in their amplitudes.

Following Table 4, it demonstrates the scenario values and the Project's NPV Simulation and Distribution columns.

Table 4: Simulation and Distribution of Project's NPV

\begin{tabular}{|c|c|c|c|c|c|c|c|c|}
\hline $\mathbf{0}$ & -RȘ & $3.232 .596,92$ & $-R S$ & $3.232 .596,92$ & $-R \$$ & $3.232 .596,92$ & -RȘ & $3.232 .596,92$ \\
\hline 1 & $\mathrm{R} \$$ & $410.887,96$ & $\mathrm{R} \$$ & $456.542,18$ & $\mathrm{R} \$$ & $502.196,40$ & & 0 \\
\hline 2 & $\mathrm{R} \$$ & $451.976,76$ & $\mathrm{R} \$$ & $502.196,40$ & $\mathrm{R} \$$ & $552.416,04$ & & 0 \\
\hline 3 & $\mathrm{R} \$$ & $497.174,43$ & $\mathrm{R} \$$ & $552.416,04$ & $\mathrm{R} \$$ & $607.657,64$ & & 0 \\
\hline 4 & $\mathrm{R} \$$ & $546.891,88$ & $\mathrm{R} \$$ & $607.657,64$ & $\mathrm{R} \$$ & $668.423,41$ & & 0 \\
\hline 5 & $\mathrm{R} \$$ & $601.581,07$ & $\mathrm{R} \$$ & $668.423,41$ & $\mathrm{R} \$$ & $735.265,75$ & & 0 \\
\hline 6 & $\mathrm{R} \$$ & $631.660,12$ & $\mathrm{R} \$$ & $701.844,58$ & $\mathrm{R} \$$ & $808.792,32$ & & 0 \\
\hline 7 & $\mathrm{R} \$$ & $663.243,12$ & $\mathrm{R} \$$ & $736.936,80$ & $\mathrm{R} \$$ & $889.671,56$ & & 0 \\
\hline 8 & $\mathrm{R} \$$ & $696.405,28$ & $\mathrm{R} \$$ & $773.783,65$ & $\mathrm{R} \$$ & $978.638,71$ & & 0 \\
\hline 9 & $R \$$ & $731.225,54$ & $\mathrm{R} \$$ & $812.472,83$ & $\mathrm{R} \$$ & $1.076 .502,58$ & & 0 \\
\hline 10 & $\mathrm{R} \$$ & $767.786,82$ & $\mathrm{R} \$$ & $853.096,47$ & $\mathrm{R} \$$ & $1.184 .152,84$ & & 0 \\
\hline Total & $\mathrm{R} \$$ & $2.766 .236,06$ & $\mathrm{R} \$$ & $3.432 .773,07$ & $\mathrm{R} \$$ & $4.771 .120,34$ & -RS & $3.232 .596,92$ \\
\hline
\end{tabular}

This same comparison was made for the Project's Total Balance. After the simulation was carried out, it was possible to obtain some information, such as: frequency chart, minimum, average and maximum project balance, median, among other information. 


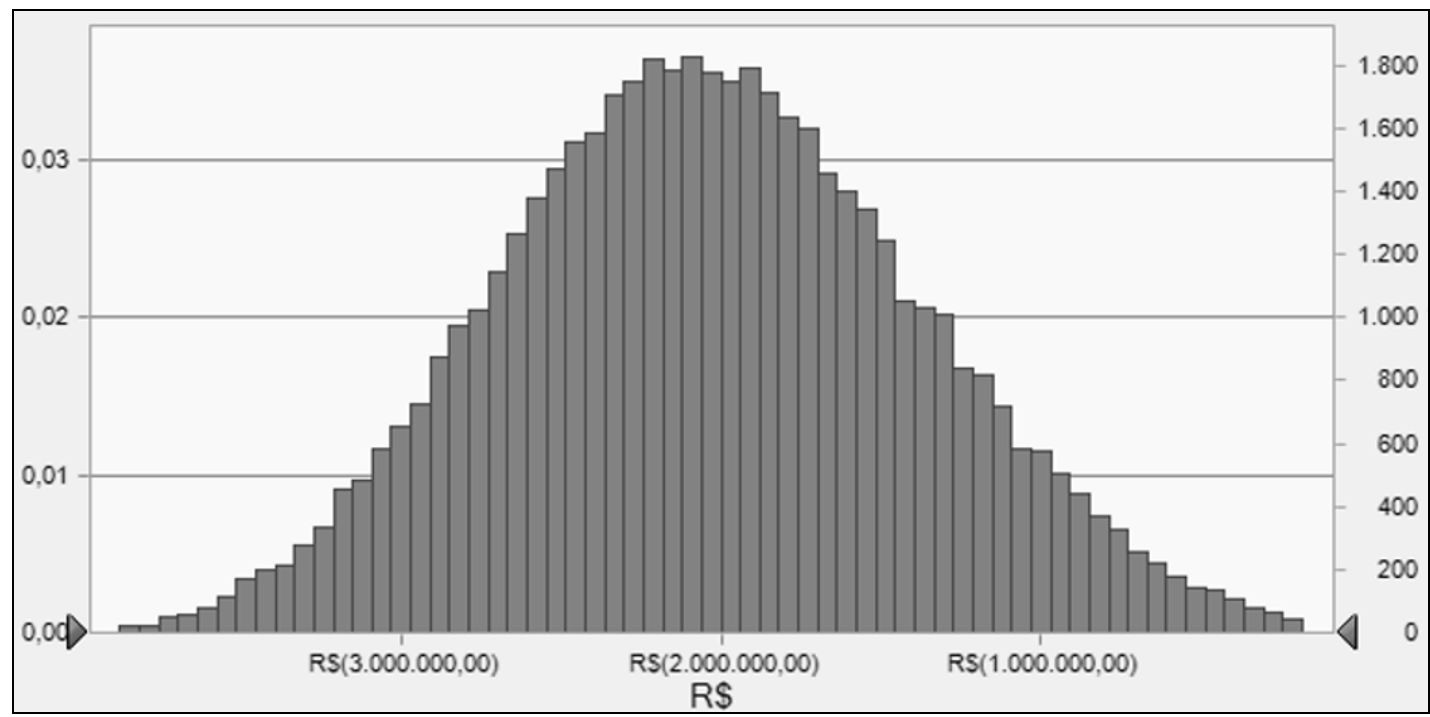

Figure 2: Frequency Graph of Project's Total Balance forecast

Through the simulation, it was possible to observe that the average obtained for the project's total balance was $\mathrm{R} \$ 2,032,881.16$. This amount is greater than the Balance of the actual scenario, estimated at $R \$ 3,432,773.07$. The minimum value found in the simulation for the project's total balance was $R \$ 4,338,842.46$. This amount was higher than the pessimistic balance that was $R \$ 2,766,236.06$. The maximum balance found in the simulation was $R \$ 657,440.14$. This amount is lower than the optimistic balance that was $\mathrm{R} \$ 4,771,120.34$.

According to Rodrigues et al. (2010), Monte Carlo simulation acts as a decision-making tool in the decision-making of investment in risk. This fact justifies the reason why this tool makes mathematical simulations that refer to a real system, allowing investors the decision to evaluate the impacts of the independent variables, represented by the assumptions arbitrated to the project, in the dependent variables, mentioned as decisive variables, significantly improving the quality of their decisions.

Table 5 below demonstrates the scenario values and the Project's Balance Simulation and Distribution columns. 
INDEPENDENT JOURNAL OF MANAGEMENT \& PRODUCTION (IJM\&P)

http://www.ijmp.jor.br

v. 8, n. 4, October - December 2017

ISSN: 2236-269X

DOI: 10.14807/ijmp.v8i4.662

Table 5: Simulation and Distribution of Project's Total Balance

\begin{tabular}{|c|c|c|c|c|c|c|c|c|}
\hline $\mathbf{0}$ & $-\mathrm{R} \$$ & $3.232 .596,92$ & $-R S$ & $3.232 .596,92$ & $-\mathrm{RSS}$ & $3.232 .596,92$ & $-\mathrm{R} S \hat{S}$ & $3.232 .596,92$ \\
\hline 1 & $-\mathrm{R} \$$ & $2.821 .708,96$ & $-\mathrm{RS}$ & $2.776 .054,74$ & $-R S$ & $2.730 .400,52$ & & 0 \\
\hline 2 & $-\mathrm{R} \$$ & $2.369 .732,20$ & $-\mathrm{R} S$ & $2.273 .858,34$ & $-R S$ & $2.177 .984,48$ & & 0 \\
\hline 3 & $-\mathrm{R} S$ & $1.872 .557,77$ & $-\mathrm{RS}$ & $1.721 .442,30$ & -RȘ & $1.570 .326,84$ & & 0 \\
\hline 4 & $-\mathrm{RSS}$ & $1.325 .665,89$ & $-\mathrm{RS}$ & $1.113 .784,66$ & $-R S \hat{S}$ & $901.903,43$ & & 0 \\
\hline 5 & $-\mathrm{R} S \mathrm{~s}$ & $724.084,82$ & -RS\$ & $445.361,26$ & $-R S \hat{S}$ & $166.637,68$ & & 0 \\
\hline 6 & -RȘ & $92.424,70$ & $\mathrm{RS}$ & $256.483,32$ & $\mathrm{R} \$$ & $642.154,65$ & & 0 \\
\hline 7 & $\mathrm{R} \$$ & $570.818,42$ & $\mathrm{R} \$$ & $993.420,12$ & $\mathrm{R} \$$ & $1.531 .826,20$ & & 0 \\
\hline 8 & $\mathrm{R} \$$ & $1.267 .223,70$ & $\mathrm{R} \$$ & $1.767 .203,77$ & $\mathrm{RSS}$ & $2.510 .464,91$ & & 0 \\
\hline 9 & $\mathrm{R} \$$ & $1.998 .449,24$ & $\mathrm{R} \$$ & $2.579 .676,60$ & $\mathrm{R} \$$ & $3.586 .967,50$ & & 0 \\
\hline 10 & $\mathrm{R} \$$ & $2.766 .236,06$ & $\mathrm{R} \$$ & $3.432 .773,07$ & $\mathrm{R} \$$ & $4.771 .120,34$ & & 0 \\
\hline Total & $-\mathrm{R} S$ & $5.836 .043,84$ & $-R S$ & $2.533 .541,35$ & $\mathrm{R} \$$ & $2.262 .683,74$ & $-R S$ & $3.232 .596,92$ \\
\hline
\end{tabular}

The application of Monte Carlo simulation provided the generation of estimates and projections for the project, allowing a statistical analysis of the viability, but this cannot be the only source to be considered by the decision makers, since their results are generated from values collected and analyzed by an individual, evidencing that the critical knowledge originates from the individuals involved in the project.

\section{FINAL CONSIDERATIONS}

After analyzing all the economic opportunities to acquire a hostel, it was observed that Joanópolis-SP is a very busy city and with projections of growth. Because it has the title of tourist resort, the tendency is that more and more people will go to cities with the characteristics of the tourist resorts to be able to escape the busy life. In the present work, it can be concluded that the investment in this hostel is viable, in the real and optimistic scenario, due to its satisfactory results in Payback, IRR and NPV and with this, its results were higher than expected, when compared to financial income of Fixed income.

It can be concluded that the possibilities of the NPV and the Total Balance of the project reached the most pessimistic or optimistic indexes within the simulation, is $0 \%$ because of the previously established triangular distribution. On the other hand, it is worth mentioning that each simulation in Crystal Ball will present different indicators (minimum, average, maximum, median, etc.) among them, even if they are performed with the same input values.

In addition, the work may conclude that the Monte Carlo simulation provided us with accurate information to assist in the decision making of this investment. 


\section{REFERENCES}

BATALHA, M. O. (2009) Gestão Agroindustrial, 3 ed. São Paulo: Atlas.

BRUNI, A. L.; FAMÁ, R.; SIQUEIRA, J. O. (1998) Análise do risco na avaliação de projetos de investimento: uma aplicação do Método de Monte Carlo. Cadernos de Pesquisa em Administração, v. 1, n. 6, p. 62-74.

CABRAL, B. M. C. (2016) Analysis of the Viability of a Rural Tourism Investment. Dissertation (Master in Financy). Lisbon: School of Economics and Management.

COOPER, C.; HALL, M.; TRIGO, L. G. G. (2011) Turismo Contemporâneo. Rio de Janeiro: Elsevier.

CORREIA NETO, J. F.; MOURA, H. J.; FORTE, S. H. A. C. (2002) Modelo prático de previsão de fluxo de caixa operacional para empresas comerciais considerando os efeitos do risco, através do método de Monte Carlo. REAd - Revista Eletrônica de Administração, v. 8, n. 3, p. 1-23.

DOUCET, A. (2004) Sequential Monte Carlo methods. In: (Ed.). Encyclopedia of statistical sciences. Hoboken, NJ: John Wiley \& Sons, Inc.

GALLON, A. V; SILVA, T. D; HEIN, N.; OLINQUEVITCH, J. L. (2006) Utilização da análise de investimento nas empresas de tecnologia do vale de Itajaí/SC. In: SIMPÓSIO DE GESTÃO DA INOVAÇÃO TECNOLÓGICA, 24, Gramado, Proceedings... Gramado: ANPAD, 2006.

GARCIA, S.; LUSTOSA, P. R. B.; BARROS, N. R. (2010) Aplicabilidade do método de simulação de Monte Carlo na previsão dos custos de produção de companhias industriais: o caso da Companhia Vale do Rio Doce. Revista de Contabilidade e Organizações, v. 4, n. 10, p. 152-173.

GIL, A. C. (2002) Como elaborar projetos de pesquisa, 4 ed. São Paulo: Atlas. GITMAN, L. J. (2002) Princípios de administração financeira, 7 ed. São Paulo: Harbra.

IRES, A. S. P. C. (2013) Plano de Negócios: Turismo em Espaço Rural na Serra de Tomar. Dissertation (Master in Tourism). Estoril: ESHTE.

JERÔNIMO, C. E. M. (2013) Estudo de viabilidade econômica aplicado a um projeto agroindustrial: Análise de sensibilidade. Revista de Administração de Roraima, v. 3, n. 2, p. 156-180. doi: http://dx.doi.org/10.18227/rarr.v3i2.790

KOTLER, P.; KELLER, K. L. (2012) Administração de marketing, 14 ed. São Paulo: Pearson.

LAPPONI, J. C. (2000) Projetos de investimento: construção e avaliação do fluxo de caixa: modelos em Excel. São Paulo: Laponni.

LUSTOSA, P. R. B.; PONTE, V. M. R.; DOMINAS, W. R. (2004) Simulação. In: CORRAR, L. J.; THEÓPHILO, C. R. (Org.). Pesquisa Operacional para decisão em contabilidade e administração. São Paulo: Atlas.

MALHOTRA, N. K. (2010) Marketing research: an applied orientation, 6 ed. Upper Saddle River, NJ: Prentice Hall. 
MARQUEZAN, L. H. F.; BRANDONI, G. (2006) Análise de Investimentos. Revista Eletrônica de Contabilidade, v. 3, n. 1, p. 1-15. doi: http://dx.doi.org/10.5902/198109466137

MAXIMIANO, A. C. A. (2011) Introdução à administração, 2 ed. São Paulo: Atlas. MOORE, J. H.; WEATHERFORD, L. R. (2005) Tomada de Decisão em Administração com Planilhas Eletrônicas, 6 ed. Porto Alegre: Bookman. MOTTA, R. R.; CALÔBA, G. M. (2002) Análise de investimentos: tomada de decisão em projetos industriais. São Paulo: Atlas.

OLIVEIRA, M. H. F. (2008) A avaliação econômico-financeira de investimentos sob condições de incerteza: uma comparação entre o método de Monte Carlo e o VPL fuzzy. Dissertation (Master in Production Engineering). São Paulo: USP.

RODRIGUES, E. M.; NUNES, R. V.; ADRIANO, N. A. (2010) A simulação de Monte Carlo como instrumento para a análise econômico-financeira em investimentos de risco - O caso de uma decisão de investimento na abertura de uma filial para revenda de equipamentos pesados no Estado do Ceará. In: CONGRESSO BRASILEIRO DE CUSTOS, 17, Belo Horizonte, Proceedings... Belo Horizonte: CBC, 2010.

SAMANEZ, C. P. (2011) Matemática Financeira: aplicações à análise e investimentos. São Paulo: Prentice Hall.

SANOVICZ, E. (2011) Turismo em Cidades. São Paulo: Campus.

SARAIVA JÚNIOR, A. F.; TABOSA, C. M.; COSTA, R. P. (2011) Simulação de Monte Carlo aplicada à análise econômica de pedido. Production Journal (Revista Produção), v. 21, n. 1, p. 149-164. doi: http://dx.doi.org/10.1590/S010365132011005000016

SILVA, N. P.; FRANCISCO, A. C.; THOMAZ, M. S. (2010) Turismo rural como fonte de renda das propriedades rurais: um estudo de caso de uma pousada rural na Região dos Campos Gerais no Estado do Paraná. Caderno Virtual de Turismo, v. 10, n. 2, p. 22-37.

STAKE, R. E. (2000) Case studies. In: DENZIN, N. K.; LINCOLN, Y. (Eds.). Handbook of qualitative research, $2 \mathrm{ed}$. Thousand Oaks: Sage.

SVIECH, V.; MANTOVAN, E. A. (2013) Análise de investimentos: controvérsias na utilização da TIR e VPL na comparação de projetos. Percurso, v. 13, n. 1, p. 270298.

YIN, R. K. (2001) Estudo de Caso: planejamento e métodos, 3 ed. Porto Alegre: Bookman. 